\title{
The impact of human resource management practices and career satisfaction on employee's turn- over intention
}

\author{
Omar Aburumman ${ }^{a^{*}}$, Ahmad Salleh ${ }^{\mathrm{a}}$, Khatijah Omar ${ }^{\mathrm{a}}$ and Mohammad Abadi ${ }^{\mathrm{b}}$
}

${ }^{a}$ School of Maritime Business and Management, Universiti Malaysia Terengganu, Malaysia

${ }^{b}$ Faculty of Business, Al-Balqa' Applied University, Jordan

\section{H R O N I C L E \\ A B S T R A C T}

Article history:

Received: June 282019

Received in revised format: July

302019

Accepted: September 9, 2019

Available online:

September 10,2019

Keywords:

HRM Practices

Employees Turnover Intention

Career Satisfaction

\begin{abstract}
Banks in Jordan are facing a crisis related to their employees, where it has recently become clear that employees are leaving their jobs in increasing numbers. Thus, this study examined the impact of the human resources management (HRM) practices (compensation, performance appraisal, promotion, and training \& development) on employee's turnover intention and the mediating role of career satisfaction. The survey questionnaire was gathered from 394 employees located in 25 banks in Jordan. The study used PLS-SEM to get the results and examine the hypotheses. The findings indicate that HRM practices (compensation, performance appraisal, promotion, and training \& development) negatively impact employees' turnover intention, and career satisfaction partially mediated the relationship between HRM practices (compensation, performance appraisal, promotion, and training \& development) and employee's turnover intention. The study recommends that banks in Jordan provide a high compensation, fair performance appraisal, fast promotion systems, sufficient training \& development program and high level of career satisfaction to maintain the human element and reduce the employees' turnover intention. Future studies may include other practices such as employee empowerment, teamwork, employment security information sharing, and job description.
\end{abstract}

\section{Introduction}

Presently, banks are exposed to intense competition in the national and international markets, great change in the external and internal environment, the increasing demands by stakeholders to achieve the goals, aspirations, and profits required from banks to deliver best services and innovations to customers (Rowland et al., 2017). These pressures and requirements fall on managers and employees in all levels of the hierarchy, thus, they must have the knowledge, skills, and abilities related to their work to achieve integration between all levels of the hierarchy in order to achieve the aspirations and objectives to both stakeholders and customers (Suifan \& Al-Janini, 2017). The annual report of the Association of Jordanian banks (2017) states that banks in Jordan are faced with problems of employees leaving the work. This is because the offers provided to employees from bank management such as compensation systems, appraisal systems, and promotion systems do not fit the needs and employees' aspirations. The report also indicated that the percentage of employees leaving their bank career is increasing each year. The researchers in Jordanian banking sector suggest that this increase could be the result of the ineffective HRM practices and a significant decrease in the level of satisfaction for employees (Madanat \& Khasawneh, 2018; Al-Abdullat \& Dababneh, 2018). Al-Abbadi (2018) stated that the banks should fulfill the employees' wishes, because they are the main driver of the banking business and banks cannot carry out their works in the absence of talented employees.

Turnover intention is an ongoing issue to researchers and organizations in the context of business organizations, where this issue still a concern for many organizations to nowadays (Hancock et al., 2013; Li et al., 2019). Researchers considered that

* Corresponding author.

E-mail address: ojrromar@gmail.com (O. Aburumman) 
the turnover intention of employees is a serious issue because high turnover intention will generate high stress for employees in the workplace and prohibit employees from increasing their loyalty and their commitment toward their work (Lin et al, 2017). In addition, management will outlay more costs in the attracting and training of new employees due to the high employees' turnover rate (Juhdi et al., 2013). Thus, employee turnover intention is very costly and has become a crucial factor that can affect the overall for organizational performance (Busari et al., 2017). Shah and Beh (2016) pointed out that employees' turnover intention is not only an issue in Western countries, but it is also a dangerous problem facing organizations in Asian countries. At the local level, Jordanian banks face a significant increase in employee turnover (Kasasbeh, 2018). For example, a study of Al-Quraan (2016) found that employees' turnover intention in Jordanian banks sector can also cause abundant and sometimes irreparable damage to these organizations, because the human factor is an element that is difficult to imitate, and continuity of banks in the markets need the permanence of the human element. In addition, when leaving these employees will take with them the skills and work procedures they have acquired and thus will present these banks with the problem of "workflow" because skilled employees' turnover (Nantsupawat et al., 2017). Thus, the current research purposes to search about factors that lead to increasing employees' turnover intention by examining the impact of HRM practices and career satisfaction on employees' turnover intention in Jordanian banks sector. Kong et al. (2012), indicated that increase career satisfaction for employees contributes to reducing the employee's turnover intention. The literature that studied career satisfaction in the Arab world and Jordan is rare because their focus was on job satisfaction (Malkawi, 2016). On the other hand, Lang et al. (2016) confirmed that most of the literature examining the relationship between career satisfaction and employees' turnover intention occurred in the West (e.g. UK, USA, and Germany), but there is an urgent need to study it in other countries, and evaluate the measurements of these dimensions from several sources. The literature that studied HRM practices did not focus on the dimensions that are associated to employee well-being, for example, the compensation, career promotion, career orientation, and safety and health, which could impact on the employee's turnover intention (Srirangam et al., 2018). Hassan et al. (2013) explained that there is a relationship between HRM practices (e.g. training systems provided by organizations) and career satisfaction, but the nature of the relationship is still under consideration and it has not been identified. On the other hand, Jyoti et al. (2015) recommend that researchers should in the future explore more mediating variables between HRM practices and employees' turnover intention. Table 1 shows the research gab and the extent of the contribution of the current study in the literature related to these variables.

Table 1

Research Gap

\begin{tabular}{|c|c|c|c|c|c|c|c|c|c|c|}
\hline Author/Year & $\begin{array}{c}\text { COM } \\
\text { and ETI }\end{array}$ & $\begin{array}{l}\text { PA and } \\
\text { ETI }\end{array}$ & $\begin{array}{c}\text { PRO } \\
\text { and ETI }\end{array}$ & $\begin{array}{c}\text { T\&D } \\
\text { and ETI }\end{array}$ & $\begin{array}{c}\mathrm{COM} \\
\text { and } \mathrm{CS}\end{array}$ & $\begin{array}{c}\mathrm{PA} \\
\text { and } \mathrm{CS}\end{array}$ & $\begin{array}{c}\text { PRO } \\
\text { and CS }\end{array}$ & $\begin{array}{c}\text { T\&D } \\
\text { and CS }\end{array}$ & $\begin{array}{l}\text { CS and } \\
\text { ETI }\end{array}$ & SET \\
\hline Lee et al.(2018) & & $\sqrt{ }$ & & $\sqrt{ }$ & & & & & & \\
\hline Alkalha et al. (2012) & & $\sqrt{ }$ & & $\sqrt{ }$ & & & & & & \\
\hline Duarte et al.(2015) & & $\sqrt{ }$ & $\sqrt{ }$ & $\sqrt{ }$ & & & & & & $\sqrt{ }$ \\
\hline BaniMelhem et al. (2018) & $\sqrt{ }$ & $\sqrt{ }$ & & $\sqrt{ }$ & & & & & & $\sqrt{ }$ \\
\hline Santhanam et al. (2017) & $\sqrt{ }$ & & & $\sqrt{ }$ & & & & & & $\sqrt{ }$ \\
\hline Busari et al. (2017) & & & $\sqrt{ }$ & & & & & & & \\
\hline Queiri \& Dwaika (2016) & & & & $\sqrt{ }$ & & & & & & \\
\hline Chen et al. (2018) & & & $\sqrt{ }$ & & & & & & & \\
\hline Yap et al. (2010) & & & & & $\sqrt{ }$ & & $\sqrt{ }$ & & & \\
\hline Yean \& Yahya (2013) & & & & & $\sqrt{ }$ & $\sqrt{ }$ & & $\sqrt{ }$ & & \\
\hline Hee et al. (2016) & & & & & $\sqrt{ }$ & $\sqrt{ }$ & & $\sqrt{ }$ & & \\
\hline $\begin{array}{c}\text { Madanat \& Khasawne } \\
\text { (2018) }\end{array}$ & & & & & $\sqrt{ }$ & $\sqrt{ }$ & & $\sqrt{ }$ & & \\
\hline Mahatanankon(2007) & & & & & & & $\sqrt{ }$ & & & \\
\hline Jung \& Takeuchi (2018) & & & & & $\sqrt{ }$ & $\sqrt{ }$ & & $\sqrt{ }$ & & $\sqrt{ }$ \\
\hline Chan \& Mai (2015) & & & & & & & & & $\sqrt{ }$ & \\
\hline Guan et al. (2014) & & & & & & & & & $\sqrt{ }$ & $\sqrt{ }$ \\
\hline Joo \& Park (2010) & & & & & & & & & $\sqrt{ }$ & \\
\hline Chan et al. (2016) & & & & & & & & & $\sqrt{ }$ & \\
\hline Ahmed (2017) & & & & & & & & & $\sqrt{ }$ & \\
\hline Current Study & $\sqrt{ }$ & $\sqrt{ }$ & $\sqrt{ }$ & $\sqrt{ }$ & $\sqrt{ }$ & $\sqrt{ }$ & $\sqrt{ }$ & $\sqrt{ }$ & $\sqrt{ }$ & $\sqrt{ }$ \\
\hline
\end{tabular}

Note: COM: Compensation, PA: Performance Appraisal, PRO: Promotion, T\&D: Training and Development, CS: Career Satisfaction, ETI: Employees Turnover Intention, SET: Social Exchange Theory

\section{Literature review}

\subsection{Employees Turnover Intention}

The concept appeared of "turnover intention" or "intention to leave" from Porter and Steers (1973, p 153), which they defined it as "the next logical step after experienced dissatisfaction in the withdrawal process". Employees" turnover intention is the ability of the employee to quit the work, which is classified as voluntary and involuntary discrimination, in addition to its dysfunction in the job that led to quitting the work, and that each type of employee turnover affects the organization to varying and different degrees (Long et al., 2012), where employees' turnover intention is formed when the individuals feel their job does not meet their ambitions and expectations (Zeffane \& Bani Melhem, 2017). The concept of employees' turnover intention has not expanded in the last 10 years, where the researchers relied on the models developed by Porter and Steers (1973), Mobley (1977). According to Arshadi and Damiri (2013), intention to leave is a conscious decision to get for alternative 
employment opportunities in other companies, this is due to different factors and reasons that prompted employees to leave their jobs. From the point of view of Thirapatsakun et al. (2014), employee turnover intention is divided into three main components as follows: (1) thinking to leave the work; (2) intention to look about a new job and (3) actual leave.

\subsection{HRM Practices}

HRM Practices have been defined as "a set of distinct but interrelated activities, functions, and processes that are directed at attracting, developing, and maintaining (or disposing) a firm's human resource" (Lado \& Wilson, 1994, p. 701). HRM practices in many organizations are mostly involved in operations, systems and issues of setting compensation, development of individuals and recruiting. However, when HRM practices adopt a strategic role, it focuses on producing high performance in the near future (Pfeffer, 2005). The investments in the HRM practices adopted by the organizations will contribute to creating organization-specific human capital that is difficult to imitate and will contribute to improving the knowledge, skills, and abilities of the employees, reduce the number who leave the organization, and increase their motivation for work (Huselid, 1995). In addition, HRM practices that aim to develop employees' abilities, opportunities, motivation and which balance between their lives and work are considered effective practices and widely accepted by employees and organizations (Blom et al., 2018). Hiltrop (1996) presents eleven practices for HRM, which can be used as a checklist for evaluating the effectiveness of HRM practices. Although several HRM practices can be introduced as dimensions, this study would focus on four practices, which are compensation, performance appraisal, promotion, and training \& development. These practices were selected for their solid connotation with the study's variables. It is widely believed that these dimensions have the possibility of motivating employees and help prevent employees from leaving their work by offering them some level of safety, independence, continuity and opportunity to achieve career satisfaction (Hee et al., 2016; Busari et al., 2017; Gadi \& Kee, 2018).

\subsection{Career Satisfaction}

Career satisfaction is defined as "the satisfaction that stems from intrinsic and extrinsic parts of their careers" (Judge et al., 1995, p. 487). Career satisfaction reflects the satisfaction for employees with internal aspects (e.g. compensation and promotion) and external aspects (e.g. performance appraisal and training \& development) along their career (Seibert \& Kraimer, 2001), which is considered as a result of work-related psychological consequence accumulated for the employee through work experience (Judge et al., 1995; Kang et al., 2015), which include outcomes for employees well-being and the quality of their life-career (Stauffer et al., 2018). Career satisfaction is abstracted in the present study as an individual subjective evaluation for the level of success, which they have attained in their job fully (Judge \& Kammeyer-Mueller, 2007), and we focus on career satisfaction as an important factor, because it has the ability to contribute to reducing the employee's turnover intention (Chan \& Mai, 2015). There are a few main reasons to study the career satisfaction of employees. First, career satisfaction is an important variable, where it reflects feelings the employees have about the work environment, and the extent of achievements which have been achieved by employees in their career lives (Van Der Weijden et al., 2016). Second, the researchers began investigating the sources of career satisfaction. For instance, Hee et al. (2016) found that career satisfaction is an outcome of diverse and effective HRM practices. Thus, the employees are appraisers of the progress they have achieved in their careers, are able to evaluate their career success and whether they want to stay or leave their work through a level of career satisfaction which they have achieved in their work (Spurk et al., 2015; Nie et al., 2018). Third, career satisfaction is more appropriate with the objectives and variables of the current study, because it is expected to explain the relationship between HRM practices and employee turnover intention.

\section{Theoretical Framework}

\subsection{Hypotheses Development}

HRM practices contribute to develop and raise the level of skills, knowledge, and commitment of employees, thus, employees are empowered to work and motivate themselves to continue their careers, and increase their desire to stay longer at work (Yousaf et al., 2018). High compensation systems and fair performance appraisal systems are the most important HRM practices associated with employee turnover intention, because they are the main driver of employees' intention to stay or leave the work (Rubel \& Kee, 2015; Shaukat et al., 2017; Dechawatanapaisal, 2018). Moreover, the lack of promotion speed and training \& development programs that do not contribute to the progress and growth of employees are considered as the reasons to drive employees to leave work (Busari et al., 2017; Santhanam et al.,2017). The following hypotheses are drawn from the above discussion:

H1a: Compensation will be negatively related to employee's turnover intention.

H1b: Performance appraisal will be negatively related to employee's turnover intention.

H1c: Promotion will be negatively related to employee's turnover intention.

H1d: Training and development will be negatively related to employee's turnover intention.

The effective use of HRM practices contributes to suit the needs of employees to increasing the level of career satisfaction for employees and increasing employee's correlation with their organizations (Yean \& Yahya, 2013). Using compensation systems and performance appraisal based on equitable reward may lead to increase the productivity and employee's loyalty, decrease the bias in work environment and increase the level of career satisfaction of employees (Howell et al., 2016; Hee et al., 2016). In addition, promotion to high positions, receiving a high salary, and training \& development programs which 
ensure career progression and performance improvement, will lead the employees to a highly satisfied about the career (Karatepe \& Vatankhah, 2015; Ahmed, 2017). The following hypotheses are drawn from the above discussion:

H2a: There is a positive relationship between compensation and career satisfaction.

H2b: There is a positive relationship between performance appraisal and career satisfaction.

H2c: There is a positive relationship between promotion and career satisfaction.

H2d: There is a positive relationship training \& development and career satisfaction.

Career satisfaction is an important indicator of employees' turnover intention, and employees who have the intention to stay and not leave their organizations have a high level of satisfaction for their career (Egan et al., 2004). Thus, organizations must expend greater effort to better understand and improve career satisfaction, which can help to decrease the employee turnover intention (Direnzo \& Greenhaus, 2011). Recent research has revealed that career satisfaction is negatively related with employees' turnover intention (Chan \& Mai, 2015; Kang et al., 2015; Chan et al., 2016; Guan et al., 2014, 2017). The following hypothesis is drawn from the above discussion:

H3: Career satisfaction will be negatively related to employee's turnover intention.

Previous studies show that the relationship between HRM practices and employees' turnover intention is not a direct relationship, and may be mediated by other variables (Allen et al., 2003; Duarte et al, 2015; Dechawatanapaisal, 2018; Srirangam et al., 2018). Career satisfaction can be used as a mediator in the mentioned relationship (Karatepe, 2012; Chan \& Mai, 2015; Zopiatis et al., 2018). According to social exchange theory (Blau, 1964), the current study suggests that career satisfaction for employees should mediate the expected negative relationship between HRM practices and employees' turnover intention. The following hypotheses are drawn from the above discussion:

H4a: Career satisfaction mediates the relationship between compensation and employee's turnover intention.

H4b: Career satisfaction mediates the relationship between performance appraisal and employee's turnover intention.

H4c: Career satisfaction mediates the relationship between promotion and employee's turnover intention.

H4d: Career satisfaction mediates the relationship between training \& development and employee's turnover intention.

\subsection{Research Model}

The theoretical framework of the current study was developed through a model of Peterson (2004) as it corresponds to the variables of the current study. The model of Peterson (2004) highlights the part played by the human resource management and other internal factors (e.g. HRM practices) over which the organization has large control in influencing the intentions of employees to leave or stay in work. Peterson (2004) confirmed that intentions to leave ultimately lead to actual turnover, and that intention, goals, commitment, and satisfaction are factors over which the organization has substantial control and over which HRM can play a critical role in controlling it. There are factors that are external to the organization, and which the organization has no control over (e.g. socialization). The focus of this model is on internal organizational behaviors that the organization has substantial control over. Many studies in the field of turnover intention have been focused on job satisfaction as a mediating variable (Poon, 2004; Liu et al., 2010; Kuo et al., 2014; Huang \& Su, 2016). This meaning that the focus has not been on career satisfaction (Kong et al., 2016). There is a marked difference between career satisfaction and job satisfaction; career satisfaction is broader and more comprehensive than job satisfaction; in career satisfaction case, the employee is satisfied with all aspects of the career such as promotion, administrative decisions, achievement and income (Chan \& Mai, 2015), while job satisfaction is associated with the work environment (Raziq \& Maulabakhsh, 2015). In the current study, HRM practices were selected as an independent variable and career satisfaction as a mediating variable, because they're managed by HRM and it conforms to the model of Peterson. Fig. 1 shows the research model of the current study.

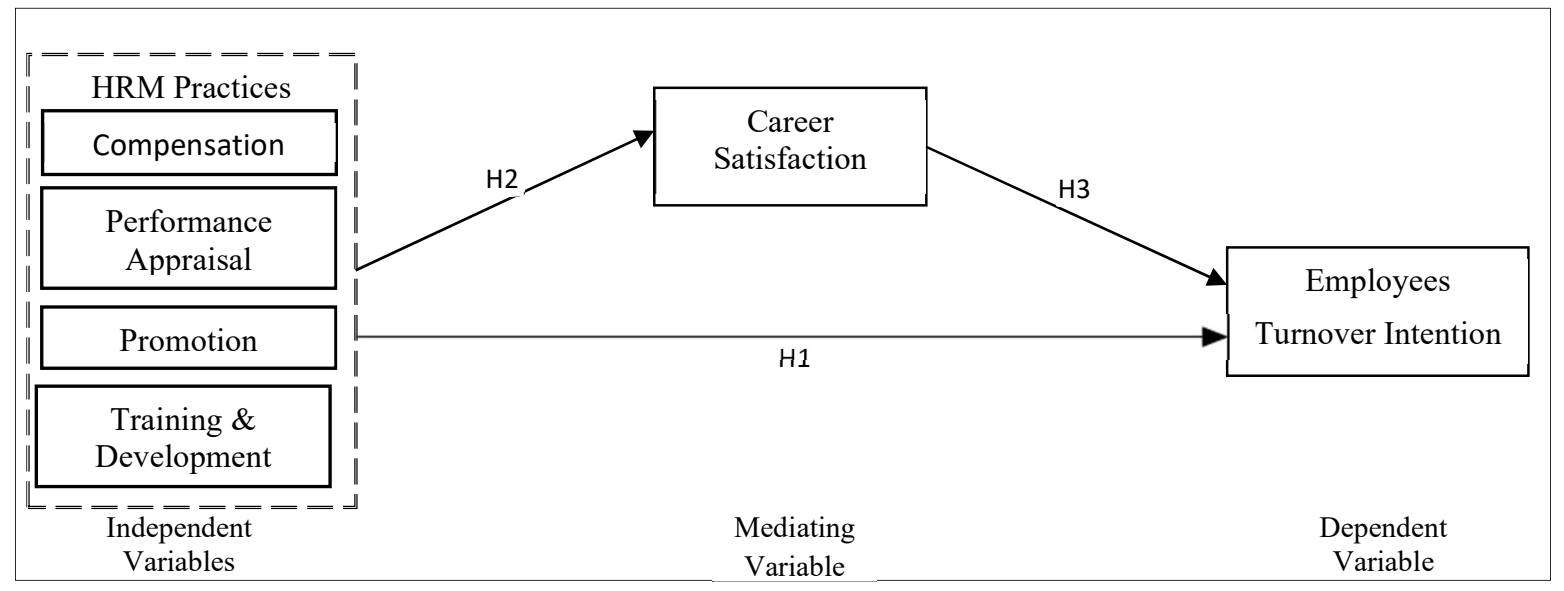

Fig. 1. Research Model 


\section{Research Methodology}

\subsection{Population, Sample Size, and Respondent}

The current study adopted a quantitative research design method based on a survey questionnaire (cross-sectional study). According to the Association of banks in Jordan for the annual report for 2017, the Jordanian banking sector consists of 25 banks (Commercial, Islamic and Foreign) and the number of employees in the Jordanian banks sector is 21090 employees. The study sample included the main management and main branches for these banks in the Amman capital, where it contains $81 \%$ of the total number of employees in the Jordanian banks sector. As for the respondents to study are all employees in Jordanian banks sector for the three management levels (general manager, regional directors, heads of department/ deputies, branch managers/deputies, supervisors, and front-line employees). According to the table of Krejcie and Morgan (1970), a sample size of 377-379 should be obtained from participants ranging from 20000-30000. Thus, the researcher selected 379 as the sample size. On the other hand, As stated by Creswell (2012), the larger the sample size, the higher will be the confidence level, the smaller will be the error variance, the better will be a representation of results, the more homogenous will be the sample. Thus, we have added a $20 \%$ to the study sample, to become a sample study $455(20 \% \times 379)$ employees from the Jordanian banking sector. This was done after recommendations of Hair et al. (2010) to reduce the sampling error, to take care of non-response bias and reduce from a problem the missing questionnaire. The method of the stratified random sample was used for data collection from respondents, because it fits in with the current study. The study sample was divided into 25 strata (each stratum represents one bank). Then, within strata, we have used the simple random sampling method to select the respondent from each stratum. All banks in Jordan agreed to participate in the current study through the filling in the questionnaire. The questionnaire was distributed with the assistance of one employee of the human resources department to distribute the questionnaire randomly. The total number of responses was 394 which represent 86.6 percent of the number of distributed questionnaires were taken for further analysis, and a total of 61 questionnaires were missing.

\subsection{Measurements of Study}

HRM Practices: Measurements of Lee et al. (2010) and Mostafa et al. (2015) were used to measure HRM practices in 17 items. In measurements of Lee et al. (2010), the compensation was measured in four items, performance appraisal in five items, training \& development in four items, and achieved reliability of $0.87,0.70$ and 0.77 , respectively. In the measurement of Mostafa et al. (2015), the promotion was measured in four items, and achieved the reliability of 0.94. Career Satisfaction: Measurement of Greenhaus et al., (1990) was used to measure career satisfaction in five items. These items have been used in many previous studies with a consistently top reliability outcome of 0.88 . Employees Turnover Intention: Measurement of Kuvaas (2008) was used to measure employee's turnover intention in five items, which carried out in a Norwegian setting. These items have been used in many previous studies with a consistently top reliability outcome of 0.74 . All variables were measured by used a 5-point Likert scale.

\subsection{Demographic Information of Respondents}

Fig. 2 shows the demographic information for 394 respondents in the current study. The results of the analysis indicate that 223 respondents are male and 171 respondents are female. The age group from 21 to 25 years is the largest group to employees in the Jordanian banking sector, it reached about 93 respondents. Regarding the job position, 239 respondents were in the lower level of management, 126 respondents were in the middle level of management, 29 respondents were in the top level of management. Finally, 162 respondents get a monthly salary from 250 to $500 \$$ and it is the largest group to employees in the Jordanian banking sector.

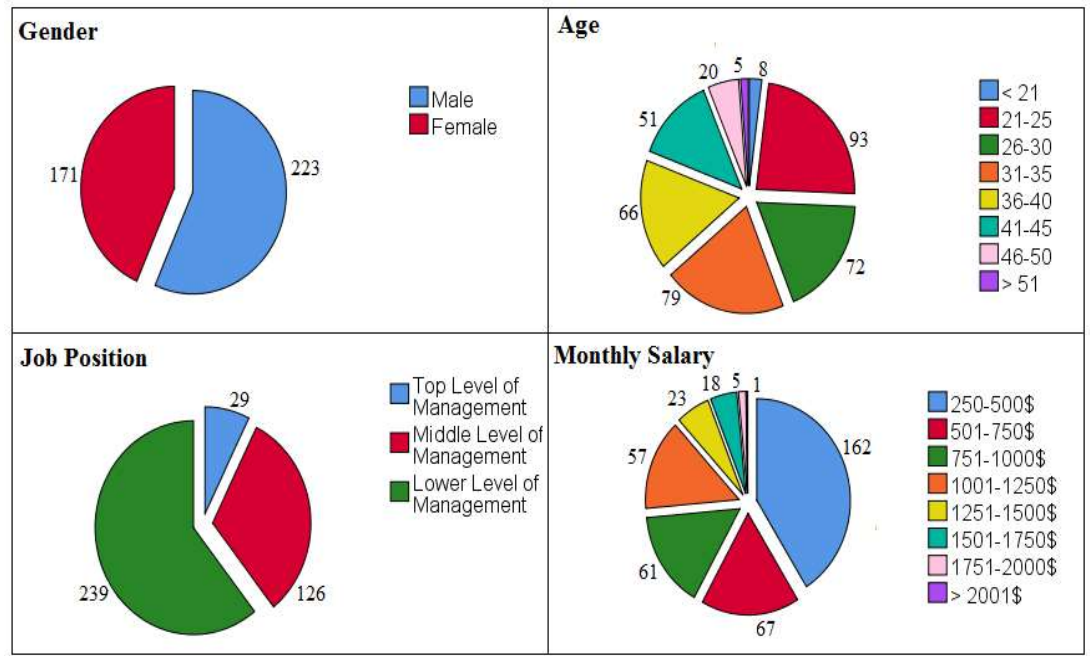

Fig. 2. Demographic Information of Respondents 


\section{Data Analysis and Results}

The first step to data analysis was descriptive statistics analysis by using the software SPSS version 25 . Table 2 shows the findings of the descriptive statistics of the variables. The mean for all variables ranged from 2.861 to 3.533 , and the standard deviation for all variables ranged from 0.956 to 1.124 .

Table 2

Descriptive Statistics of The Variables

\begin{tabular}{|c|c|c|c|c|c|}
\hline \multicolumn{2}{|c|}{ Variable } & $\mathrm{N}$ & Mean & Std. Deviation & Variance \\
\hline \multirow{4}{*}{ 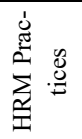 } & Compensation & 394 & 3.062 & 1.036 & 1.074 \\
\hline & Performance Appraisal & 394 & 3.533 & 1.116 & 1.246 \\
\hline & Promotion & 394 & 3.358 & .956 & .914 \\
\hline & Training and Development & 394 & 3.300 & 1.073 & 1.152 \\
\hline \multicolumn{2}{|c|}{ Career Satisfaction } & 394 & 3.056 & 1.124 & 1.266 \\
\hline \multicolumn{2}{|c|}{ Employees Turnover Intention } & 394 & 2.861 & 1.117 & 1.248 \\
\hline
\end{tabular}

Note: Five-points scale: $1=$ strongly disagree; $5=$ strongly agree

\subsection{Measurement Model Assessment}

Based on recommendations of Hair et al. (2017), the measurement model was an assessment by two aspects including convergent validity and discriminant validity. In convergent validity, we must retain the items that achieve loading more than 0.70 , Cronbach's alpha and composite reliability should be more than 0.7 and AVE should be more than 0.5 . Table 3 shows the results of convergent validity analysis, and it achieved the minimum requirement suggested by Hair et al. (2017). Thus, all latent constructs in the current study are valid and reliable.

Table 3

Convergent Validity Analysis

\begin{tabular}{|c|c|c|c|c|c|c|}
\hline \multicolumn{2}{|c|}{ Variable } & \multirow[t]{2}{*}{ Items } & \multirow{2}{*}{$\begin{array}{c}\text { Factor } \\
\text { Loadings }\end{array}$} & \multirow{2}{*}{$\begin{array}{c}\text { Cronbach's } \\
\text { Alpha }\end{array}$} & \multirow{2}{*}{$\begin{array}{l}\text { Composite } \\
\text { Reliability }\end{array}$} & \multirow[t]{2}{*}{ AVE } \\
\hline \multirow{18}{*}{ 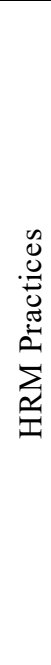 } & \multirow{5}{*}{ Compensation } & & & & & \\
\hline & & COM1 & 0.708 & 0.864 & 0.906 & 0.709 \\
\hline & & COM2 & 0.887 & & & \\
\hline & & COM3 & 0.874 & & & \\
\hline & & COM4 & 0.887 & & & \\
\hline & \multirow[t]{5}{*}{ Performance Appraisal } & PA1 & 0.886 & 0.924 & 0.943 & 0.767 \\
\hline & & PA2 & 0.867 & & & \\
\hline & & PA3 & 0.890 & & & \\
\hline & & PA4 & 0.890 & & & \\
\hline & & PA5 & 0.844 & & & \\
\hline & \multirow[t]{4}{*}{ Promotion } & PRO1 & 0.860 & 0.851 & 0.900 & 0.692 \\
\hline & & PRO2 & 0.800 & & & \\
\hline & & PRO3 & 0.876 & & & \\
\hline & & PRO4 & 0.787 & & & \\
\hline & \multirow[t]{4}{*}{ Training \& Development } & T\&D1 & 0.850 & 0.885 & 0.920 & 0.743 \\
\hline & & $\mathrm{T} \& \mathrm{D} 2$ & 0.889 & & & \\
\hline & & T\&D3 & 0.852 & & & \\
\hline & & T\&D4 & 0.857 & & & \\
\hline \multirow{5}{*}{\multicolumn{2}{|c|}{ Career Satisfaction }} & CS1 & 0.818 & 0.904 & 0.929 & 0.724 \\
\hline & & $\mathrm{CS} 2$ & 0.885 & & & \\
\hline & & $\mathrm{CS} 3$ & 0.878 & & & \\
\hline & & CS4 & 0.842 & & & \\
\hline & & CS5 & 0.828 & & & \\
\hline \multirow{5}{*}{\multicolumn{2}{|c|}{ Employees Turnover Intention }} & ETI1 & 0.745 & 0.909 & 0.932 & 0.735 \\
\hline & & ETI2 & 0.875 & & & \\
\hline & & ETI3 & 0.912 & & & \\
\hline & & ETI4 & 0.857 & & & \\
\hline & & ETI5 & 0.887 & & & \\
\hline
\end{tabular}

Note: COM: Compensation, PA: Performance Appraisal, PRO: Promotion, T\&D: Training and Development, CS: Career Satisfaction, ETI: Employees Turnover Intention

Regarding the discriminant validity, Table 4 shows the results of discriminant validity based on Fornell-Larcker Criterion, where the results indicate that construct has discriminant validity based on recommendations of (Henseler et al., 2016). 
Table 4

Discriminant Validity Based on Fornell-Larcker Criteria

\begin{tabular}{|c|c|c|c|c|c|c|}
\hline \multicolumn{7}{|c|}{ Fornell-Larcker Criterion } \\
\hline & $\mathrm{COM}$ & PA & PRO & $\mathrm{T} \& \mathrm{D}$ & $\mathrm{CS}$ & ETI \\
\hline $\mathrm{COM}$ & 0.842 & & & & & \\
\hline PA & 0.249 & 0.876 & & & & \\
\hline PRO & 0.229 & 0.328 & 0.832 & & & \\
\hline $\mathrm{T} \& \mathrm{D}$ & 0.141 & -0.045 & 0.237 & 0.862 & & \\
\hline CS & 0.399 & 0.519 & 0.613 & 0.289 & 0.851 & \\
\hline ETI & -0.440 & -0.489 & -0.595 & -0.313 & -0.819 & 0.857 \\
\hline
\end{tabular}

Note: COM: Compensation, PA: Performance Appraisal, PRO: Promotion, T\&D: Training and Development, CS: Career Satisfaction, ETI: Employees Turnover Intention

\subsection{Structural Model Assessment}

Structural model assessment includes the coefficient of determination $\left(\mathrm{R}^{2}\right)$ and path coefficients (Hypotheses Testing). Table 5 shows the $\mathrm{R}^{2}$ values for the endogenous latent variables based on recommendations of Chin (1998). These results indicate the structural model developed in the current study has predictive accuracy.

Table 5

The $\mathrm{R}^{2}$ Values for The Endogenous Latent Variables

\begin{tabular}{lcc}
\hline Endogenous Variable & $\mathbf{R}^{\mathbf{2}}$ & Predictive Relevance \\
\hline Career Satisfaction (CS) & 0.561 & Moderate \\
Employees Turnover Intention (ETI) & 0.712 & Substantial \\
\hline
\end{tabular}

Regarding the path coefficients (Hypotheses Testing), the current study used a PLS algorithm and bootstrapping techniques embedded with Smart PLS version 3.2.8 with 5000 bootstrap samples. Fig. 3 shows the results of the structural model.

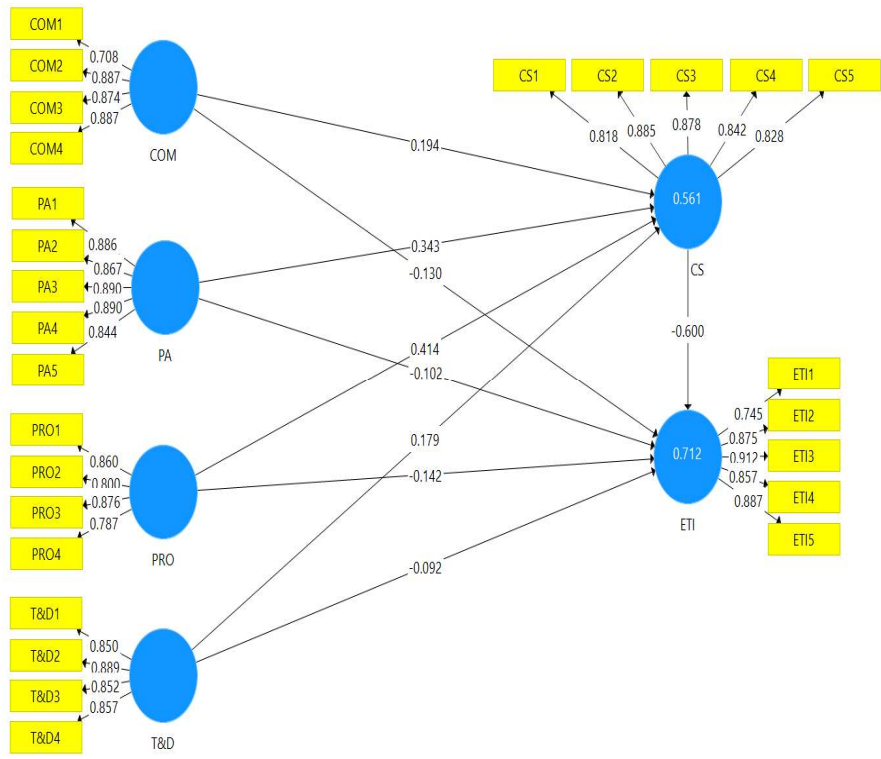

Fig. 3. Results of the Structural Model Based on P-Value

Table 6 shows the path coefficient values and e bootstrapping results for hypothesized relationships between study variables. As indicated in Table 6, compensation had a negative direct effect on employee's turnover intention $(\beta=-0.130 ; t=4.589 ; p$ $<0.001)$, as a result, $\mathrm{H}_{1 \mathrm{a}}$ was supported. Performance appraisal had a negative direct effect on employee's turnover intention $(\beta=-0.102 ; \mathrm{t}=2.864 ; \mathrm{p}<0.01)$, as a result, $\mathrm{H}_{1 \mathrm{~b}}$ was supported. Promotion had a negative direct effect on employee's turnover intention $(\beta=-0.142 ; \mathrm{t}=2.941 ; \mathrm{p}<0.01)$, as a result, $\mathrm{H}_{1 \mathrm{c}}$ was supported. Training and development had a negative direct effect on employee's turnover intention $(\beta=-0.092 ; \mathrm{t}=2.628 ; \mathrm{p}<0.01)$, as a result, $\mathrm{H}_{1 \mathrm{~d}}$ was supported. According to these results, the employees in Jordanian banks sector are working in an environment with ineffective HRM practices, will respond to such an environment by displaying the intention to leave work. Compensation is the most HRM practice that negatively impacts an employee's turnover intention followed by promotion, performance appraisal, and training \& development respectively. The current study highlighted that HRM practices caused negative emotions that affected the employee's turnover intention. Therefore, when employees realize that their organizations' compensations do not commensurate with their needs 
and desires, there are some unfair performance appraisal, promotion speeds are low, training \& development programs do not contribute to improve the job performance, they may leave work. These observations are in line with previous results (Santhanam et al., 2017; Busari et al., 2017; Yousaf et al, 2018; Srirangam et al., 2018).

Table 6

Hypotheses Testing (Direct Effect)

\begin{tabular}{|c|c|c|c|c|c|c|}
\hline No. & Hypotheses & Path Coefficient & Standard Error & $\begin{array}{c}\text { T-Value } \\
\text { (T Statistics) }\end{array}$ & P-Value & Decision \\
\hline H1a & $\mathrm{COM} \rightarrow \mathrm{ETI}$ & -0.130 & 0.028 & 4.589 & 0.000 & Supported*** \\
\hline $\mathrm{H} 1 \mathrm{~b}$ & $\mathrm{PA} \rightarrow \mathrm{ETI}$ & -0.102 & 0.036 & 2.864 & 0.004 & Supported** \\
\hline $\mathrm{H} 1 \mathrm{c}$ & $\mathrm{PRO} \rightarrow \mathrm{ETI}$ & -0.142 & 0.048 & 2.941 & 0.003 & Supported** \\
\hline H1d & $\mathrm{T} \& \mathrm{D} \rightarrow \mathrm{ETI}$ & -0.092 & 0.035 & 2.628 & 0.009 & Supported** \\
\hline $\mathrm{H} 2 \mathrm{a}$ & $\mathrm{COM} \rightarrow \mathrm{CS}$ & 0.194 & 0.034 & 5.718 & 0.000 & Supported*** \\
\hline $\mathrm{H} 2 \mathrm{~b}$ & $\mathrm{PA} \rightarrow \mathrm{CS}$ & 0.343 & 0.040 & 8.691 & 0.000 & Supported $* * *$ \\
\hline $\mathrm{H} 2 \mathrm{c}$ & $\mathrm{PRO} \rightarrow \mathrm{CS}$ & 0.414 & 0.043 & 9.569 & 0.000 & Supported*** \\
\hline $\mathrm{H} 2 \mathrm{~d}$ & $\mathrm{~T} \& \mathrm{D} \rightarrow \mathrm{CS}$ & 0.179 & 0.037 & 4.865 & 0.000 & Supported $* * *$ \\
\hline H3 & $\mathrm{CS} \rightarrow$ ETI & -0.600 & 0.043 & 14.025 & 0.000 & Supported*** \\
\hline
\end{tabular}

Note: 5,000 bootstrap samples

As indicated in Table 6, compensation had a positive direct effect on career satisfaction $(\beta=0.194 ; \mathrm{t}=5.718 ; \mathrm{p}<0.001)$, as a result, $\mathrm{H}_{2 \mathrm{a}}$ was supported. Performance appraisal had a positive direct effect on career satisfaction $(\beta=0.343 ; \mathrm{t}=8.691 ; \mathrm{p}$ $<0.001)$, as a result, $\mathrm{H}_{2 \mathrm{~b}}$ was supported. Promotion had a positive direct effect on career satisfaction $(\beta=0.414 ; \mathrm{t}=9.569 ; \mathrm{p}$ $<0.001)$, as a result, $\mathrm{H}_{2 \mathrm{c}}$ was supported. Training and development had a positive direct effect on career satisfaction $(\beta=$ $0.179 ; \mathrm{t}=4.865 ; \mathrm{p}<0.001)$, as a result, $\mathrm{H}_{2 \mathrm{~d}}$ was supported. According to these findings, that HRM practices of compensation, performance appraisal, promotion, and training \& development have significant positive impacts on career satisfaction. Therefore, if organizations provided to employees' a high compensation and benefits, fair performance appraisal based on equitable compensation and rewards, fast promotion systems based on performance and qualifications and provide sufficient training $\&$ development program, then we expect that to see an increase in the level of career satisfaction and employees stay longer at work. These observations are in line with previous results (Karatepe \& Vatankhah, 2015; Saxena \& Rai, 2016; Hee et al., 2016; Lee et al., 2017, 2018).

Additionally, the results showed that career satisfaction had a negative effect on employee's turnover intention ( $\beta=-0.600$; $\mathrm{t}=14.025 ; \mathrm{p}<0.001$ ), as a result, $\mathrm{H}_{3}$ was supported. The results were consistent with those reported by previous researchers (Chan \& Mai, 2015; Chan et al., 2016; Guan et al., 2017) who highlighted that employees that have a high level of career satisfaction may have the intention to keep working for their firms. The current study used the method of Preachers and Hayes (2008) and recommended by Zhao et al. (2010) for mediating the necessary tests, through bootstrapping techniques embedded with Smart PLS 3.2.8. There are two main steps to mediation test using the method of Preacher and Hayes (2008). The first step is bootstrap for the indirect effect, which is associated with the relationships between independent variables and a dependent variable via mediator. The second step is bootstrapped confidence interval (lower level and upper level). Table 9 shows the results of mediating test.

Table 7

Results of Mediating Test

\begin{tabular}{|c|c|c|c|c|c|c|c|c|}
\hline \multirow{2}{*}{ Hypothesis } & \multirow{2}{*}{ Path a } & \multirow{2}{*}{ Path b } & \multirow{2}{*}{$\begin{array}{l}\text { Indirect Ef- } \\
\text { fect }\end{array}$} & \multirow{2}{*}{ SE } & \multirow{2}{*}{ T-value } & \multicolumn{2}{|c|}{ Confidence Interval } & \multirow{2}{*}{ Decision } \\
\hline & & & & & & $95 \% \mathrm{LL}$ & $95 \% \mathrm{UL}$ & \\
\hline $\begin{array}{l}\mathrm{H} 4 \mathrm{a} \\
\mathrm{COM} \rightarrow \mathrm{CS} \rightarrow \mathrm{ETI}\end{array}$ & 0.194 & -0.600 & -0.116 & 0.034 & -3.424 & -0.183 & -0.050 & Partial Mediation \\
\hline $\begin{array}{l}\mathrm{H} 4 \mathrm{~b} \\
\mathrm{PA} \rightarrow \mathrm{CS} \rightarrow \mathrm{ETI}\end{array}$ & 0.343 & -0.600 & -0.206 & 0.042 & -4.900 & -0.288 & -0.123 & Partial Mediation \\
\hline $\begin{array}{l}\mathrm{H} 4 \mathrm{c} \\
\mathrm{PRO} \rightarrow \mathrm{CS} \rightarrow \mathrm{ETI}\end{array}$ & 0.414 & -0.600 & -0.248 & 0.044 & -5.645 & -0.335 & -0.162 & Partial Mediation \\
\hline $\begin{array}{l}\mathrm{H} 4 \mathrm{~d} \\
\mathrm{~T} \& \mathrm{D} \rightarrow \mathrm{CS} \rightarrow \mathrm{ETI}\end{array}$ & 0.179 & -0.600 & -0.107 & 0.040 & -2.685 & -0.186 & -0.029 & Partial Mediation \\
\hline
\end{tabular}

Note: LL: Lower Level, UL: Upper Level

Note: 5,000 bootstrap samples

As indicated in Table 7, Career satisfaction mediates the relationship between compensation and employee's turnover intention (Indirect Effect $=-0.116, \mathrm{p}<0.001, \mathrm{LL}=-0.183, \mathrm{UL}=-0.050$ ), as a result, $\mathrm{H}_{4 \mathrm{a}}$ was supported and the career satisfaction (CS) partially mediated this relationship. Career satisfaction mediates the relationship between performance appraisal and employee's turnover intention (Indirect Effect $=-0.206, \mathrm{p}<0.001, \mathrm{LL}=-0.288, \mathrm{UL}=-0.123$ ), as a result, $\mathrm{H}_{4 \mathrm{~b}}$ was supported and the career satisfaction (CS) partially mediated this relationship. Career satisfaction mediates the relationship between promotion and employee's turnover intention (Indirect Effect $=-0.248, \mathrm{p}<0.001, \mathrm{LL}=-0.335, \mathrm{UL}=-0.162$ ), as a result, $\mathrm{H}_{4 \mathrm{c}}$ 
was supported and the career satisfaction (CS) partially mediated this relationship. Career satisfaction mediates the relationship between training \& development and employee's turnover intention (Indirect Effect $=-0.107, \mathrm{p}<0.001, \mathrm{LL}=-0.186$, $\mathrm{UL}=-0.029$ ), as a result, $\mathrm{H}_{4 \mathrm{~d}}$ was supported and the career satisfaction (CS) partially mediated this relationship.

According to these findings, when compensation systems, performance appraisal, career promotion, and training \& development programs are satisfactory to employees and reflect the intrinsic and extrinsic aspects of career satisfaction, then employees have less turnover intention and increase their motivation at work. These findings support previous suggestions (Duarte et al., 2015; Dechawatanapaisal, 2018; Srirangam et al., 2018).

\section{Conclusions and Future Directions}

The current study focused primarily on the employee's turnover intention, through looking at factors that affect the turnover intention, which includes HRM practices (compensation, performance appraisal, promotion, and training \& development) and career satisfaction. The current study found that HRM practices and career satisfaction had a significant negative impact on employee turnover intentions. In addition, career satisfaction partially mediated the relationship between HRM practices (compensation, performance appraisal, promotion, and training \& development) and employee's turnover intention.

Social exchange theory for Blau (1964) supported these relationships. The researchers stressed that this theory is based on the principle of reciprocity, whether positive or negative, that is to say if any party makes a positive commitment, the other party will make a positive commitment, and if any party makes a negative commitment, the other party will make a negative commitment (Cropanzano \& Mitchell, 2005). Therefore, if organizations provide a positive behaviour such as a high compensation and benefits, fair performance appraisal, fast promotion systems, and sufficient training \& development program; the employees will behave similarly and will commit to positive behaviours by staying longer and demonstrating a high commitment and satisfaction.

This study was limited to four main practices which are compensation, performance appraisal, promotion, and training \& development. Therefore, future studies may include other practices such as employee empowerment, teamwork, employment security information sharing, and job description.

\section{References}

Ahmed, N. O. A. (2017). Career commitment: the role of self-efficacy, career satisfaction and organizational commitment. World Journal of Entrepreneurship, Management and Sustainable Development, (just-accepted), 00-00.

Al-Abbadi, L. H. M. (2018). Impact of Human Resources Management Practices on Organizational Commitment of the Employees of Commercial Banks in Jordan. Global Journal of Management and Business Research, 18(4),11-21.

Al-Abdullat, B. M., \& Dababneh, A. (2018). The mediating effect of job satisfaction on the relationship between organizational culture and knowledge management in Jordanian banking sector. Benchmarking: An International Journal, 25(2), 517-544.

Alkalha, Z., Al-Zu'bi, Z., Al-Dmour, H., Alshurideh, M., \& Masa'deh, R. (2012). Investigating the effects of human resource policies on organizational performance: An empirical study on commercial banks operating in Jordan. European Journal of Economics, Finance and Administrative Sciences, 51(1), 44-64.

Allen, D. G., Shore, L. M., \& Griffeth, R. W. (2003). The role of perceived organizational support and supportive human resource practices in the turnover process. Journal of management, 29(1), 99-118.

Al-Quraan, A. B. (2016). Impact of Transformational Leadership on Organizational Commitment: Case Study at Jordan Ahli Bank. European Journal of Business and Management, 8(31),145-156.

Arshadi, N., \& Damiri, H. (2013). The relationship of job stress with turnover intention and job performance: Moderating role of OBSE. Procedia-Social and Behavioral Sciences, 84, 706-710.

Association of Banks in Jordan. (2017). Annual Report. Retrieved January 23, 2019, from http://abj.org.jo/ar-jo/Annual-Reports-ar-JO.

BaniMelhem, H., Elanain, H. M. A., \& Hussain, M. (2018). Impact of Human Resource Management Practices on Employees' Turnover Intention in United Arab Emirates (UAE) Health Care Services. International Journal of Information Systems in the Service Sector (IJISSS), 10(4), 21-41.

Blau, P. M. (1964). Exchange and power in social life. New York: John Wiley and Sons.

Blom, R., Kruyen, P. M., Van der Heijden, B. I., \& Van Thiel, S. (2018). One HRM fits all? A meta-analysis of the effects of HRM practices in the public, semipublic, and private sector. Review of Public Personnel Administration,1-33.

Busari, A. H., Mughal, Y. H., Khan, S. N., Rasool, S., \& Kiyani, A. A. (2017). Analytical cognitive style moderation on promotion and turnover intention. Journal of Management Development, 36(3), 438-464.

Chan, S. H. J., \& Mai, X. (2015). The relation of career adaptability to satisfaction and turnover intentions. Journal of Vocational Behavior, 89, 130-139.

Chan, S. H., Mai, X., Kuok, O. M., \& Kong, S. H. (2016). The influence of satisfaction and promotability on the relation between career adaptability and turnover intentions. Journal of Vocational Behavior, 92, 167-175. 
Chen, H., Li, G., Li, M., Lyu, L., \& Zhang, T. (2018). A cross-sectional study on nurse turnover intention and influencing factors in Jiangsu Province, China. International Journal of Nursing Sciences, 5(4), 396-402.

Chin, W. W. (1998). The partial least squares approach to structural equation modeling. Modern Methods for Business Research, 295(2), 295-336.

Creswell, J. W. (2012). Educational research: Planning, conducting, and evaluating quantitative and qualitative research (4th ed.). Boston, MA: Pearson Education

Cropanzano, R., \& Mitchell, M. S. (2005). Social exchange theory: An interdisciplinary review. Journal of management, 31(6), 874-900.

Dechawatanapaisal, D. (2018). Examining the relationships between HR practices, organizational job embeddedness, job satisfaction, and quit intention: Evidence from Thai accountants. Asia-Pacific Journal of Business Administration, 10(2/3), 130-148.

Direnzo, M., \& Greenhaus, J. H. (2011). Job search and voluntary turnover in a boundaryless world: A control theory perspective. Academy of Management Review, 36(3), 567-589.

Duarte, A. P., Gomes, D., \& Neves, J. (2015). Satisfaction with human resource management practices and turnover intention in a five-star hotel: The mediating role of perceived organizational support. Dos Algarves: A Multidisciplinary e-Journal, (25), 103-123.

Egan, T. M., Yang, B., \& Bartlett, K. R. (2004). The effects of organizational learning culture and job satisfaction on motivation to transfer learning and turnover intention. Human Resource Development Quarterly, 15(3), 279-301.

Gadi, P. D., \& Kee, D. H. M. (2018). Human Resource Management Practices and Turnover Intention: The Mediating Role of Perceived Organizational Support in Tertiary Institutions in Nigeria. International Journal of Engineering \& Technology, 7(3.25), 715-722.

Greenhaus, J. H., Parasuraman, S., \& Wormley, W. M. (1990). Effects of race on organizational experiences, job performance evaluations and career outcomes. Academy of Management Journal, 33(1), 64-86.

Guan, Y., Jiang, P., Wang, Z., Mo, Z., \& Zhu, F. (2017). Self-referent and other-referent career successes, career satisfaction, and turnover intention among Chinese employees: The role of achievement motivation. Journal of Career Development, 44(5), 379-393.

Guan, Y., Wen, Y., Chen, S. X., Liu, H., Si, W., Liu, Y., ... \& Dong, Z. (2014). When do salary and job level predict career satisfaction and turnover intention among Chinese managers? The role of perceived organizational career management and career anchor. European Journal of Work and Organizational Psychology, 23(4), 596-607.

Hair, J. F., Black, W. C., Babin, B. J., \& Anderson, R. E. (2010). Multivariate data analysis, a global perspective: New Jersey. Pearson. Ed 7.

Hair, J. F., Hult, G. T. M., Ringle, C. M., \& Sarstedt, M. (2017). A Primer on Partial Least Squares Structural Equation Modeling. 2nd Ed. Thousand Oaks: Sage Publications.

Hancock, J. I., Allen, D. G., Bosco, F. A., McDaniel, K. R., \& Pierce, C. A. (2013). Meta-analytic review of employee turnover as a predictor of firm performance. Journal of Management, 39(3), 573-603.

Hassan, M., Hassan, S., Khan, M. F. A., \& Iqbal, A. (2013). Impact of HR practices on employee satisfaction and employee loyalty: An empirical study of government owned public sector banks of Pakistan. Middle-East Journal of Scientific Research, 16(1), 01-08.

Hee, O. C., Cheng, T. Y., Yaw, C. C., Gee, W. V., Kamaludin, S. M., \& Prabhagaran, J. R. (2016). The Influence of Human Resource Management Practices on Career Satisfaction: Evidence from Malaysia. International Review of Management and Marketing, 6(3), 517-521.

Henseler, J., Hubona, G., \& Ray, P. A. (2016). Using PLS path modeling in new technology research: updated guidelines. Industrial Management \& Data Systems, 116(1), 2-20.

Hiltrop, J. M. (1996). A framework for diagnosing human resource management practices. European Management Journal, 14(3), 243-254.

Howell, L. P., Elsbach, K. D., \& Villablanca, A. C. (2016). The role of compensation criteria to minimize face-time bias and support faculty career flexibility: an approach to enhance career satisfaction in academic pathology. Academic pathology, 3, 1-9.

Huang, W. R., \& Su, C. H. (2016). The mediating role of job satisfaction in the relationship between job training satisfaction and turnover intentions. Industrial and Commercial Training, 48(1), 42-52.

Huselid, M. A. (1995). The impact of human resource management practices on turnover, productivity, and corporate financial performance. Academy of Management Journal, 38(3), 635-672.

Joo, B. K., \& Park, S. (2010). Career satisfaction, organizational commitment, and turnover intention: The effects of goal orientation, organizational learning culture and developmental feedback. Leadership \& Organization Development Journal, 31(6), 482-500.

Judge, T. A., Cable, D. M., Boudreau, J. W., \& Bretz Jr, R. D. (1995). An empirical investigation of the predictors of executive career success. Personnel psychology, 48(3), 485-519.

Judge, T. A., \& Kammeyer-Mueller, J. D. (2007). Personality and career success. Handbook of career studies, 59-78.

Juhdi, N., Pa'wan, F., \& Hansaram, R. M. K. (2013). HR practices and turnover intention: the mediating roles of organizational commitment and organizational engagement in a selected region in Malaysia. The International Journal of Human Resource Management, 24(15), 3002-3019. 
Jung, Y., \& Takeuchi, N. (2018). A lifespan perspective for understanding career self-management and satisfaction: The role of developmental human resource practices and organizational support. Human Relations, 71(1), 73-102.

Jyoti, J., Rani, R., \& Gandotra, R. (2015). The impact of bundled high performance human resource practices on intention to leave: Mediating role of emotional exhaustion. International Journal of Educational Management, 29(4), 431-460.

Kang, H. J., Gatling, A., \& Kim, J. (2015). The impact of supervisory support on organizational commitment, career satisfaction, and turnover intention for hospitality frontline employees. Journal of Human Resources in Hospitality \& Tourism, 14(1), 68-89.

Karatepe, O. M. (2012). Perceived organizational support, career satisfaction, and performance outcomes: a study of hotel employees in Cameroon. International Journal of Contemporary Hospitality Management, 24(5), 735-752.

Karatepe, O. M., \& Vatankhah, S. (2015). High-performance work practices, career satisfaction, and service recovery performance: a study of flight attendants. Tourism Review, 70(1), 56-71.

Kasasbeh, I. (2018). Problems of Management Accounting Implementation: The Case of Balanced Scorecard Implementation within Jordanian Commercial Banks. International Journal of Academic Research in Accounting, Finance and Management Sciences, 8(2), 200-207.

Kim, S. (2012). The impact of human resource management on state government IT employee turnover intentions. Public Personnel Management, 41(2), 257-279.

Kong, H., Cheung, C., \& Song, H. (2012). From hotel career management to employees' career satisfaction: The mediating effect of career competency. International Journal of Hospitality Management, 31(1), 76-85.

Kong, H., Sun, N., \& Yan, Q. (2016). New generation, psychological empowerment: can empowerment lead to career competencies and career satisfaction?. International Journal of Contemporary Hospitality Management, 28(11), $2553-2569$.

Krejcie, R. V., \& Morgan, D. W. (1970). Determining sample size for research activities. Educational and Psychological measurement, 30(3), 607-610.

Kuo, H. T., Lin, K. C., \& Li, I. C. (2014). The mediating effects of job satisfaction on turnover intention for long-term care nurses in Taiwan. Journal of Nursing Management, 22(2), 225-233.

Kuvaas, B. (2008). An exploration of how the employee-organization relationship affects the linkage between perception of developmental human resource practices and employee outcomes. Journal of Management Studies, 45(1), 1-25.

Lado, A. A., \& Wilson, M. C. (1994). Human resource systems and sustained competitive advantage: A competency-based perspective. Academy of Management Review, 19(4), 699-727.

Lang, J., Kern, M., \& Zapf, D. (2016). Retaining high achievers in times of demographic change. The effects of proactivity, career satisfaction and job embeddedness on voluntary turnover. Psychology, 7(13), 1545-1561.

Lee, C. I., Bosco, F. A., Steel, P., \& Uggerslev, K. L. (2017). A metaBUS-enabled meta-analysis of career satisfaction. Career Development International, 22(5), 565-582.

Lee, F. H., Lee, T. Z., \& Wu, W. Y. (2010). The relationship between human resource management practices, business strategy and firm performance: evidence from steel industry in Taiwan. The International Journal of Human Resource Management, 21(9), 1351-1372.

Lee, J., Sohn, Y. W., Kim, M., Kwon, S., \& Park, I. J. (2018). Relative Importance of Human Resource Practices on Affective Commitment and Turnover Intention in South Korea and United States. Frontiers in Psychology, 9(669), 1-12.

Li, N., Zhang, L., Xiao, G., Chen, J., \& Lu, Q. (2019). The relationship between workplace violence, job satisfaction and turnover intention in emergency nurses. International Emergency Nursing, 45,50-55.

Liu, B., Liu, J., \& Hu, J. (2010). Person-organization fit, job satisfaction, and turnover intention: An empirical study in the Chinese public sector. Social Behavior and Personality: An International Journal, 38(5), 615-625.

Long, C. S., Thean, L. Y., Ismail, W. K., \& Jusho, A. (2012). Leadership styles and employees' turnover intention: exploratory study of academic staff in a Malaysian College. World Applied Sciences Journal, 19(4), 575-581.

Madanat, H. G., \& Khasawneh, A. S. (2018). Level of effectiveness of human resource management practices and its impact on employees' satisfaction in the banking sector of Jordan. Journal of Organizational Culture, Communications and Conflict, 22(1), 1-19.

Malkawi, Z. A. (2016). Career satisfaction of Jordanian dental hygienists. International journal of dental hygiene, 14(4), 243248.

Mobley, W. H. (1977). Intermediate linkages in the relationship between job satisfaction and employee turnover. Journal of applied psychology, 62(2), 237-240.

Mostafa, A. M. S., Gould-Williams, J. S., \& Bottomley, P. (2015). High-performance human resource practices and employee outcomes: the mediating role of public service motivation. Public Administration Review, 75(5), 747-757.

Nantsupawat, A., Kunaviktikul, W., Nantsupawat, R., Wichaikhum, O. A., Thienthong, H., \& Poghosyan, L. (2017). Effects of nurse work environment on job dissatisfaction, burnout, intention to leave. International nursing review, 64(1), 91-98.

Nie, D., Lämsä, A. M., \& Pučètaitè, R. (2018). Effects of responsible human resource management practices on female employees' turnover intentions. Business Ethics: A European Review, 27(1), 29-41.

Peterson, S. (2004). Toward a theoretical model of employee turnover: A human resource development perspective. Human Resource Development Review; 3(3), 209-227.

Pfeffer, J. (2005). Changing mental models: HR 's most important task. Human Resource Management, 44, $123-128$.

Poon, J. M. (2004). Effects of performance appraisal politics on job satisfaction and turnover intention. Personnel review, 33(3), 322-334. 
Preacher, K. J., \& Hayes, A. F. (2008). Asymptotic and resampling strategies for assessing and comparing indirect effects in multiple mediator models. Behavior Research Methods, 40(3), 879-891.

Porter, L. W., \& Steers, R. M. (1973). Organizational, work, and personal factors in employee turnover and absenteeism. Psychological Bulletin, 80(2), 151-176.

Queiri, A., \& Dwaikat, N. (2016). Factors affecting Generation Y employees' intention to quit in Malaysian's business process outsourcing sector. Journal of Sustainable Development, 9(2), 78-92.

Raziq, A., \& Maulabakhsh, R. (2015). Impact of working environment on job satisfaction. Procedia Economics and Finance, 23, 717-725.

Rowland, C. A., Hall, R. D., \& Altarawneh, I. (2017). Training and development: Challenges of strategy and managing performance in Jordanian banking. EuroMed Journal of Business, 12(1), 36-51.

Rubel, M. R. B., \& Kee, D. M. H. (2015). High Commitment Compensation Practices and Employee Turnover Intention: Mediating Role of Job Satisfaction. Mediterranean Journal of Social Sciences, 6(6 S4), 321.

Santhanam, N., Dyaram, L., \& Ziegler, H. (2017). Impact of human resource management practices on employee turnover intentions: Moderating role of psychological contract breach. Journal of Indian Business Research, 9(3), 212-228.

Saxena, N., \& Rai, H. (2016). Correlations and organisational effects of compensation and benefits, job satisfaction, career satisfaction and job stress in public and private hospitals in Lucknow, India. Asia Pacific Journal of Health Management, 11(2), 65-74.

Seibert, S. E., \& Kraimer, M. L. (2001). The five-factor model of personality and career success. Journal of Vocational Behavior, 58(1), 1-21.

Shah, S. H. A., \& Beh, L. S. (2016). The impact of motivation enhancing practices and mediating role of talent engagement on turnover intentions: Evidence from Malaysia. International Review of Management and Marketing, 6(4), 823-835.

Shaukat, R., Yousaf, A., \& Sanders, K. (2017). Examining the linkages between relationship conflict, performance and turnover intentions: Role of job burnout as a mediator. International Journal of Conflict Management, 28(1), 4-23.

Spurk, D., Abele, A. E., \& Volmer, J. (2015). The career satisfaction scale in context: A test for measurement invariance across four occupational groups. Journal of Career Assessment, 23(2), 191-209.

Srirangam Ramaprasad, B., Lakshminarayanan, S., \& Pai, Y. P. (2018). The relationship between developmental HRM practices and voluntary intention to leave among IT professionals in India: the mediating role of affective commitment. Industrial and Commercial Training, 50(6), 285-304.

Stauffer, S. D., Abessolo, M., Zecca, G., \& Rossier, J. (2019). French-language translation and validation of the protean and boundaryless career attitudes scales: relationships to proactive personality, career adaptability, and career satisfaction. Journal of Career Assessment, 27(2), 337-357.

Suifan, T. S., \& Al-Janini, M. (2017). The relationship between transformational leadership and employees' creativity in the Jordanian Banking Sector. International Review of Management and Marketing, 7(2), 284-292.

Thirapatsakun, T., Kuntonbutr, C., \& Mechinda, P. (2014). The relationships among job demands, work engagement, and turnover intentions in the multiple groups of different levels of perceived organizational supports. Universal Journal of Management, 2(7), 272-285.

Van Der Weijden, I., Teelken, C., de Boer, M., \& Drost, M. (2016). Career satisfaction of postdoctoral researchers in relation to their expectations for the future. Higher Education, 72(1), 25-40.

Yap, M., Holmes, M. R., Hannan, C. A., \& Cukier, W. (2010). The relationship between diversity training, organizational commitment, and career satisfaction. Journal of European Industrial Training, 34(6), 519-538.

Yean, T. F., \& Yahya, K. K. (2013). The influence of human resource management practices and career strategy on career satisfaction of insurance agents. International Journal of Business and Society, 14(2), 193- 206.

Yousaf, A., Sanders, K., \& Yustantio, J. (2018). High commitment HRM and organizational and occupational turnover intentions: the role of organizational and occupational commitment. The International Journal of Human Resource Management, 29(10), 1661-1682.

Zeffane, R., \& Bani Melhem, S. J. (2017). Trust, job satisfaction, perceived organizational performance and turnover intention: A public-private sector comparison in the United Arab Emirates. Employee Relations, 39(7), 1148-1167.

Zhao, X., Lynch Jr, J. G., \& Chen, Q. (2010). Reconsidering Baron and Kenny: Myths and truths about mediation analysis. Journal of consumer research, 37(2), 197-206.

Zopiatis, A., Theocharous, A. L., \& Constanti, P. (2018). Career satisfaction and future intentions in the hospitality industry: An intrinsic or an extrinsic proposition?. Journal of Human Resources in Hospitality \& Tourism, 17(1), 98-120.

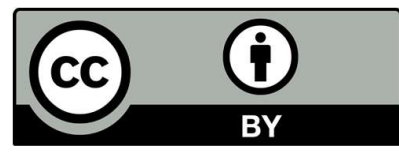

(C) 2020 by the authors; licensee Growing Science, Canada. This is an open access article distributed under the terms and conditions of the Creative Commons Attribution (CCBY) license (http://creativecommons.org/licenses/by/4.0/). 